\title{
Reflection of three prominent religious, mythological and epic themes in mystical texts
}

\section{Reflexión de tres temas religiosos, mitológicos y épicos destacados en textos místicos}

\author{
Ahmad Modir \\ Student in Persian Language and Literature, Islamic Azad University, Mashhad Branch, Iran

\section{Reza Ashrafzadeh} \\ Department of Persian Language and Literature, Islamic Azad University, Mashhad Branch, \\ Iran

\section{Javad Mehraban Ghezelhesar} \\ Department of Persian Language and Literature, Islamic Azad University, Mashhad Iran Branch
}

*Correspondence

Email: AhmadModir@gmail.com
Cite as:

\footnotetext{
Modir A., Ashrafzadeh, R., \& Ghezelhesar, J.M. (2021) Reflection of three prominent religious, mythological and epic themes in mystical texts. Propósitos $y$ Representaciones, 9 (SPE1), e936. Doi: http://dx.doi.org/10.20511/pyr2021.v9nSPE1.936
} 


\section{Summary}

Zoroaster, Jamshid and Kaykhosrow are among the personalities who have a large part of the culture and beliefs of ancient Iran. Art and literature have also provided a good platform for the widespread reflection of such wondrous themes in mystical texts. The influence of Zoroastrian teachings on the thought, culture and customs of ancient Iran is undeniable. The era of Jamshid's narration in ancient Iran and Shahnameh is highly respected for its tranquility, abundance of blessings, and abundant social services. In addition to Barkikhosrow, who is one of the virtuous and most prominent mystical figures in Avesta and Shahnameh, the epics and myths of Shahnameh have greatly influenced the mystical texts of later centuries, and mystics, referring to the myths and epics of Shahnameh, have the deepest mystical expressions. Ethical. The myth is derived from the Greek "history", meaning search, knowledge and story, and is closely linked to religious and mystical beliefs, as it contains the menu of ancient humans and the manifestation of their beliefs about the creation of the world, beings and human beings. It is worth mentioning that the main purpose of mystics in dealing with the myths and epics of Shahnameh is to express mystical themes. In this research, an attempt has been made to express three prominent religious, mythological and epic themes: Zoroaster, Jamshid, and Kaykhosrow, and how they are reflected in mystical texts, their transformation and their connections from the beginning to the stage of Islamic perfection and maturity. The method of work in this research is the use of library and written resources based on analysis and description.

Keywords: Myth, Epic, Avesta, Shahnameh, Mysticism

\section{Resumen}

Zoroastro, Jamshid y Kaykhosrow se encuentran entre las personalidades que tienen gran parte de la cultura y creencias del antiguo Irán. El arte y la literatura también han proporcionado una buena plataforma para la reflexión generalizada de temas tan maravillosos en textos místicos. La influencia de las enseñanzas de Zoroastro en el pensamiento, la cultura y las costumbres del antiguo Irán es innegable. La era de la narración de Jamshid en el antiguo Irán y Shahnameh es muy respetada por su tranquilidad, abundancia de bendiciones y abundantes servicios sociales. Además de Barkikhosrow, que es una de las figuras místicas virtuosas y más prominentes de Avesta y Shahnameh, las epopeyas y mitos de Shahnameh han influido mucho en los textos místicos de siglos posteriores, y los místicos, en referencia a los mitos y epopeyas de Shahnameh, han las expresiones místicas más profundas. Ético. El mito se deriva de la "historia" griega, que significa búsqueda, conocimiento e historia, y está estrechamente vinculado a creencias religiosas y místicas, ya que contiene el menú de los humanos antiguos y la manifestación de sus creencias sobre la creación del mundo, seres y seres humanos. Vale la pena mencionar que el propósito principal de los místicos al tratar los mitos y epopeyas de Shahnameh es expresar temas místicos. En esta investigación se ha intentado expresar tres temas religiosos, mitológicos y épicos destacados: Zoroastro, Jamshid y Kaykhosrow, y cómo se reflejan en los textos místicos, su transformación y sus conexiones desde el principio hasta la etapa de perfección islámica. y madurez. El método de trabajo en esta investigación es el uso de recursos bibliotecarios y escritos basados en análisis y descripción.

Palabras clave: Mito, Épica, Avesta, Shahnameh, Misticismo 


\section{Introduction}

Zoroaster, Jamshid, and Kaykhosrow are among the personalities who have a large part of the culture and beliefs of ancient Iran and the Shahnameh. Art and literature have also provided a suitable and wide platform for the reflection of such themes in literary and mystical texts. The influence of Zoroastrian teachings on the thought, culture, beliefs, and customs of ancient Iran is undeniable. Zoroaster and Avesta have left a remarkable effect on Shahnameh, literary and mystical texts. The era of Jamshid's narration in ancient Iran and Shahnameh is highly respected for its tranquility, abundance of blessings, and abundant social services. Kaykhosrow is also the most famous king of Kiani, who is well mentioned in Avesta and Shahnameh. In addition, Kaykhosrow is one of the most prominent mystical figures in the Shahnameh, whose lifestyles and princes in later periods became a good example for some mystics. Therefore, by comparing these three prominent religious, mythological and epic figures in Avesta, Shahnameh and mystical texts, we can find a large part of the treasure trove of culture, beliefs, ideas, and customs of our ancestors.

\section{Necessity, importance and purpose of research}

Considering that one of the main religious, mythological and epic themes in Avesta is the three characters of Zoroaster, Jamshid, and Kaykhosrow, these three prominent, great, and effective themes have had many reflections and surprising effects on the Shahnameh and mystical texts. In Shahnameh, in addition to showing the insights, wisdom and beliefs of ancient Iran, Zoroaster, Jamshid and Kaykhosrow are among the most important religious, mythological and epic themes. Mystics have also used such themes extensively in their works to express mystical, mystical, and moral concepts. Therefore, comparing these three prominent figures in Avesta, Shahnameh and mystical texts, it seems necessary to get acquainted with a large part of the culture, beliefs and thought of the ancient land of Iran

\section{.Research questions}

This study seeks to answer such questions. What is the place of Zoroaster, Jamshid and Kaykhosrow in Avesta, Shahnameh and mystical texts? What changes have they gone through from the beginning to the arrival of mystical texts? What is the main purpose of mystics in referring to such themes?

\section{Research background}

Previously, several works have been written about Zoroastrianism, Avesta, epic, myth, Shahnameh, and Iranian-Islamic mysticism, among which the following books can be mentioned: Avesta, as the largest and most enduring cultural heritage of ancient Iran, compiled and compiled Master Ebrahim Pourdavod in four volumes. From Rangolgol to Ranj Khar by Dr. Ghadmali Serami, in which the author, while telling the mystical stories of Shahnameh, has recounted their mystical features. Culture of Myths and Fictional References in Persian Literature by Dr. Yahaghi; In this book, the author has tried to show the rich underpinnings of thought and the cultural richness of Persian language and literature with a relatively comprehensive description of allusions, codes, and myths in Persian poetry and literature. Knowledge of Iranian Myths by Hinels In this book, the mystical themes of the myths are shown as mirrors, images of the customs, beliefs, culture and past history of ancient Iran. The mythological history of Iran by Dr. 
Amoozgar, in which a clear and concise picture of the beliefs of the myths of ancient Iran from the beginning to the time when the myth enters history is presented; The ancient letter of Dr. Jalaluddin Kazazi, in the report section of its verses, a relatively complete and comprehensive description of the myths and epics of the Shahnameh is given. Search in Iranian Sufism by Dr. Zarrinkoob, in which valuable explanations of Islamic mysticism and its sources are given.

\section{Research method and theoretical framework}

In this research, an attempt has been made to compare three prominent and distinguished religious figures, the myths and epics of Zoroaster, Jamshid and Kaykhosrow in Avesta, and Shahnameh, until reaching the stage of perfection and maturity of Iranian-Islamic mysticism.

The ups and downs, the course of their transformation and evolution, and the position and status of each of them should be discussed. The basis of this research is the use of library and written resources, and is based on adaptation, analysis and description. In it, while comparing each of the figures in Avesta and Shahnameh, how they are reflected in mystical texts is discussed.

\section{Analytical processing of the subject}

\section{Zoroastrianism}

The name Zarahushtar, the prophet of ancient Iran, meaning the owner of the yellow camel, in Persian has come in more than ten different forms, the most common of which is Zoroastrian or Zoroastrian. His birthplace is considered by some to be Balkh, a group of Azerbaijanis, and some by Rey. Considering that some people consider his life time to be related to six thousand years, and some to six hundred years before Xerxes Shah's expedition to Greece, Master Pourdavod believes that according to what is mentioned in Ardavirafnameh and it is more famous in the tradition, Zoroaster in $660 \mathrm{He}$ was born before Christ. (See: Pourdaoud, 1394: 1/33). Although Helens considers the time and birthplace of Zoroaster unknown, he says about the time of his life: "According to tradition, his time is around 551-628 BC. They know." (Hinels, 1397: 14). The name Zoroaster in Avesta is mostly used with the word Spitmeh; Some scholars, such as Doharla, consider the word sacred, and some, such as Darmster, consider it the family name of Zoroaster. Zoroaster, the prophet of ancient Iran, the founder of the Mazdisna religion, and the poet of the Gathas, is his oldest part. The basis of the Zoroastrian religion, which has been repeated many times in the Gathas, is based on three important principles: good thought, good speech and good deed. The teachings of Zoroaster, mixed with some of the indigenous beliefs of ancient Iran, have been the official religion of Iran for about five centuries during the Sassanid period. Effort to build the world and fight against the court and the elements of evil is one of the principles of Zoroastrian teachings. Master Purdwood believes that today there are fragments of Avesta in which, although Zoroastrianism is not mentioned, it is undoubtedly mentioned in reference to Zoroaster. As it is stated in the ninth verse of the thirty-fifth verse: "We spread this revealed word with the best character, O Ahuramazda, then we will consider you (O Zoroaster) as its narrator and teacher."

(Pourwood 1394: 3/258). The teachings of Zoroaster, as evidenced by Geoshuron's (Psychoanalytic) complaint in the Gathas about the praise of property, wealth, and effort, may not seem to be commensurate with the world of asceticism and mysticism, but given that, " "Zoroaster himself is considered to be the first herdsman, the first cleric, and the first warrior in the Mazdisan tradition, which shows that for him warfare and wealth-making are not in conflict with the spiritual worlds." (Zarrinkoob, 1369: 2). At the age of twenty, Zoroaster was subjected to mystical isolation and solitude. "In $583 \mathrm{BC}$, at the age of seventy-seven, during the invasion of the Arjasb Turani army, he was martyred in a fire temple in Balkh by a Turanian, in the words of the band," 
Barat Ruk Rash. " (Purdavud, 1394: 1/34). The religion of Zoroastrianism, which has Iranian origins, has had a tremendous impact on the flourishing of ancient Iranian culture.

According to the narrations of Shahnameh, Zoroaster, who was a contemporary of Goshtasb, presented his religion to him, and Goshtasb, after accepting his religion, set out to publish it. Arjasb Turani, after Goshtasb accepts the religion of Bahi and bans its spread, asks him to return to the religion of his ancestors so as not to be deceived by the court; And since there is no suitable answer, he engages in bloody battles between the two, the main theme of which is the story of the confrontation between Ormazd and the devil, or good and evil. In the Shahnameh of Zoroaster, Mani and Mazdak are the three great Iranian prophets, each of whom has a special role in the process of the epic events of the Shahnameh according to their unique characteristics. Zoroaster and Avesta are one of the valuable sources of Ferdowsi's work in creating Shahnameh. Zoroastrianism has a worthy image in Shahnameh and the religion of Zoroaster is introduced in it, the religion of truth, correctness and monotheism. Zoroaster is one of the heroes and prophets of Ahura. The cypress tree that brings it from heaven and places it on the Goshtasb pavilion is also an Ahura tree. It is also like this: "The chain that Zoroaster brought from heaven to Goshtasb and Esfandiar traps the magic woman in the weekly reading with its help." (Serami, 1392: 576).

A free cypress tree was dragged from heaven to the door of Azar

His writing is based on the fact that "Goshtasb accepted the religion of Bahi"

How did he spread the free cypress tree so much! (Ferdowsi, 1394: 3/41).

Given that the belief in duality is one of the salient features of Zoroastrianism, in Zoroastrian duality, good and evil do not explicitly match the Gnostic dualities with spirit and matter, because in this religion, what belongs to the realm of good is life and life. Death is like a lie about the realm of evil. Accordingly, in the teachings of Zoroaster, goodness depends on life, happiness and happiness; And the joy and happiness of some mystical elders also stem from this idea. As Saadi knows his happiness and joy from the fact that "the world belongs to him." According to the teachings of Zoroaster and his teachings, man's constant closeness to Ormazd is the source of goodness. In Pahlavi texts, myths and epic stories, or religious of the Sassanid period, there are many mystical elements that are associated withVesta and the teachings of Zoroaster are closely related. Including the story related to the end of Kaykhosrow's work, which is described in detail in the narrations used by Ferdowsi and Shahnameh. (See: Zarrinkoob, 1369: 25) .References to Zoroaster, Avesta, and Zand and Pazand have been widely reflected in religious, literary, and mystical texts. In the meantime, some mystics have mentioned it with respect, and some have looked at it with contempt. As is unjustly common among Muslims, most Muslims call Zoroastrianism a cult of fire-worship, while life-giving fire is a symbol of light, warmth, and a symbol of this religion, and "statements such as Zoroastrian fire-worship are never true, and what "Zoroastrians worship, Ahuramazda, the God of existence, the only wise." (Vahidi, 1393: 116). Roozbehan Baqli Shirazi, at the beginning of the work of love in Abhar al-Ashin, while pointing to this false belief, and denying Zand and Pazand as heavenly books, called Zand and Pazand the ritual book of Zoroaster and Mazdak, says: "Zand and Pazand are the names of two books. "Which Zoroaster and Mazdak have brought in the rulings of fire-worship, claiming to be prophets and that it is a divine book."

(Baqli Shirazi, 1987: 183) . 
Although Islam considers Zoroastrianism to be a divine prophet and according to the seventeenth verse of Surah Hajj, Zoroastrianism is included in the ranks of the heavenly religions, most Muslims from the distant past did not value Zoroastrianism as it should and called them "Gabri" to despise and humiliate Zoroastrians. And call them fire worshipers. Meanwhile, even prominent mystics such as Attar in the tragedy, while expressing his dissatisfaction with philosophers and sages, considers their method equal to the religion of Zoroastrianism and confrontation with Islamic law, and after condemning philosophy and preferring jurisprudence, commentary and hadith over other sciences : .Philosophy is the Zoroastrian method of philosophizing with the Shari'a (Attar, 2007: 7-156) .Elsewhere in the same book, he considers the conversion of Zoroastrianism to be contrary to Islam and believes :The Zoroastrian religion you have adopted is not the religion of Muhammad, son (Ibid: 427) .In the second article of the tragedy, which is in "The Seeker of Thought Goes to Israfil", Attar tells the story of the sinking of a ship in which a Zoroastrian seeks help from fire in an allegorical anecdote. In response, Mallah says to him: Be silent, O Jajkhai! That fire does not last here either. In this anecdote, Attar uses the inappropriate word of Gabr, which is "derived from the Aramaic word and the root of the Arabic infidel." (Ashrafzadeh, 1376: 133), meaning infidel and polytheist, with a kind of contempt and humiliation, has been used for Zoroastrians .He was so afraid that no one said: O fire! Scream at me The sailor said: Silence, O fire-eater, who knows here from head to toe (Ibid: 26) .Zoroaster is one of the sages who is highly regarded and respected in Suhrawardi's Enlightenment wisdom. In many cases, Sheikh Ishraq, modeled on the teachings of Zoroaster, mentions him in expressing many of his Enlightenment discussions. For example, what is mentioned in Suhrawardi's works as the "originality of light" and the evolution of the human soul, which originates from the essence of truth, is derived from the teachings of Zoroaster. Just as in Zoroastrianism, the existence of Ahuramazda is from light, so Suhrawardi, in the matter of light, calls God the light of enlightenment, and intellect or abstract light "the first being to emanate from the first origin." (Yathribi, 1385: 137) knows. In Zoroastrianism, the world is divided into two parts, light and darkness, Ormazd and Ahriman as symbols of the world of light and darkness are in constant confrontation. Accordingly, Suhrawardi, like Zoroaster, divides the world into two parts of the world of darkness, and the world of light and light, and believes that the institution of everything in this world is either the result of light or the result of darkness. Accordingly, he has classified the universe "in four categories: substantial light, transcendental light, substantial darkness (body), and dark bodies."

(Ibid: 99) .Rumi also sometimes has a perfumed attitude towards Zoroaster, and the status of fire in this. As in the story of Adam (AS) being surprised by the misguidance of Iblis, while humiliating and despising the fire and the religion of Zoroaster, he says :Whoever took refuge in the fire and turned his back became both a Magi and a Zoroastrian (Molavi, 1369: 1/184) .In a beautiful sonnet that he has written to describe his loneliness and turmoil and falling into ruin, while referring to the word Gabr, he says with a kind of contempt and contempt :A reed with which he raised a tail with him, a Muharram reed that he found with him, a reed of obedience, no reed took his hand.Given that the Mehr worshipers in the Mehri religion believed that by drinking, one can attain a spiritual state, be aware of the mysteries of the unseen, so the influence of such beliefs in the Vedic, Zoroastrian and Christian religions, Zoroastrians also have special rituals to perform this ritual. They were paying. Based on these beliefs, Hafez, the famous poet of the eighth century, while alluding to the story of Nimrod and Ibrahim (AS), and referring to the place and status of fire and wind ritual in Zoroastrian religion in which Zoroastrian priests and clerics with special wind rituals around fire They were paying, he says :Renew the Zoroastrian religion to the garden now that the tulip is lit, the fire does not die (Hafez, 1371: 298) .While in mystical lyric 
poems, Hafez takes a person from the carpet to the throne, in Saqinameh, he criticizes the pleasure of living, describing the wind and the butler and referring to the name of Zoroaster, and the status and position of fire and may in this ritual. He tried to make Jamjam drink to him immediately.

Come on, butler, don't jam me

Be the butler of the radiant fire that Zoroaster seeks under the ground (Hafez, 1372: 661).

Jami, the famous mystic of the ninth century, unlike other mystics, in the following verses, while implicitly referring to the life, morals and character of Abraham and Zoroaster, promotes some human qualities such as kindness, generosity, self-sacrifice, forgiveness and avoiding persecution of others. Says:

Expand it on everyone who reads the cream, spread it on everyone, if you are a Zoroastrian, suck on each other, open your back to each other, open your hands to the sacrifice of all, open your hands to the sacrifice of all

(Hekmat, 1363: 290).

\section{Jamshid}

Jamshid is the son of Wyonghan in Avesta. His name is also mentioned in Sanskrit as "yam" and in the Gathas as "yim", and in the adjectives "shid", which means bright, good, and "sireh", which means beautiful. Jamshid has been mentioned frequently and well in various sources such as Rig Veda, Bandeshan, various parts of Avesta such as Farvardin, Isht, Abanisht, Artisht, Zamiadisht, Pahlavi, Pazand, Persian, and Tazi writings. Myths about Jamshid, with some differences, go back to the common beliefs of the Indo-Iranian period. According to what is mentioned in Iranian myths and Shahnameh, the long period of Jamshid's rule has been mentioned with great respect. The most important characteristics of his reign are peace, abundance of blessings, and much social service. However, "wherever he is spoken of, the end of his kingdom is ugly." (Purdaud, 1394: 1/628). The existence of similar myths beyond Jamshid in European myths indicates that this myth dates back to the time of India and Europe. Heinz quotes Rig Veda as the first person to die. $\mathrm{He}$ is also mentioned as a sinner. (See: Hinells, 1397: 6-55). The fact that Jamshid had both a divine lineage and a priestly status shows that "in ancient Iran, the Shahriars also had a religious leadership, and the Giti and Minoo were intertwined in them." (Kazazi, 1383: 1/263). According to the legends of Jamshid, after three hundred years of reign, he built "Var" to save the people from the storm that the gods had predicted. There was a garden adorned like a paradise around Jamshid. Predicting the Flood and making it to save people is very similar to the story of Noah's Flood in religious myths. "Jamshid is known in Iranian mythology in many ways, and few can be compared to him in this regard. He sent and chose Ahura Mazda to earth. "He is both a king and a priest and a warrior." (Molaei, 1368: 158). According to Avestan narrations, Jamshid has a pair called "Yam" or "Yimak" which, like Mashi and Mashianeh, are considered as the first human couple. In parts 3 to 5 of chapter 23 of Bandeshhan, and Hat 9 of Yasna, Jam and his sister Jamak are also mentioned. Jamshid was the first to offer the sacred plant Hum to Ormazd. In the second round, when Zoroaster asks Ahura Mazda, O Ahuramazda, with whom did you speak before and teach him the religion of Zoroaster? He hears the answer: "The first person with whom I spoke before you, holy Zarathustra, and to whom I taught the religion of Ahuramazda, the religion of Zarathustra, was a beautiful woman with a lot of rum." (Pourdaoud, 1394: 4/510). Then 
Ahuramazda offered him a prophet but Jam did not accept it. As stated in Fargard 17 of Bandeshshan, in Jamshid's time, three firefighters appeared to support three groups of people in the world: (Ibid., 3/381).

According to the narrations of Shahnameh, Jamshid is the fourth king of the Pishdadian dynasty, who succeeded to the throne after Tahmurth and ruled for seven hundred years. During his reign, he built tools of war and house. Teaches people about treatment and medicine. Celebrates the celebration of the century. Divides society into four groups and defines the duties of each. In the end, he suffers from selfishness and claims God. For this reason, the divine forehead breaks from him, the people turn away from him, and finally he is cut in two by Zahak with a saw. However, the reign of Jamshid is the period of victory over nature and demons, and the ideal paradise of the ancient Iranians. Ferdowsi considers Jamshid's destruction in ingratitude to God and says in the position of advice:

To God, whoever became ungrateful enters his heart with fear from all sides (Ferdowsi, 1394: $1 / 24)$.

The myth of Jamshid has been widely reflected in mystical texts, and mystics have made many references to this myth in order to express various mystical, mystical and moral themes. As Muhammad ibn Munawwar, in a satirical account of the mysteries of monotheism, mentions the name of this mythical king among the people of Hell, he quotes that one day in the House of Bousaid, Sheikh Bu Abdullah Abdullah of Baku was sitting; Bo Saeed sees him in such a state. Someone says to the sheikh: May God bless you in heaven! The sheikh speaks in a mixture mixed with humor. "Do not make us a paradise in which there are a handful of lame, Luke, Darwish, loose, blind and weak. We should be made hell, Jamshid Droo and Pharaoh Droo and Haman Droo and Khajeh Droo and point to Sheikh Bu Abdullah and we reap and point to ourselves. Sheikh Bo Abdullah broke down and came with him and knew that a great Turk had left him. "He repented with himself." (Mohammad Ibn Munawwar, 1371: 1/208).

In the storiesIn mythology, literary and mystical texts, the name of Jamshid is mixed with Jamjam. According to myths and theology, the cup or cup of the universe was a cup on which the astronomical figures of the stars and the week of the earth were engraved, and in which everything that happened in the distance was mysteriously displayed. In Shahnameh, there is no mention of Jamshid being attributed to Jamjam or Gitiunma Cup; And Ferdowsi has attributed it to Kaykhosrow. In the story of Bijan and Manijeh, looking at him in Jupiter of the day, he became aware of the well in which Bijan was trapped, promised Gio to save his son, and sent Rustam to bring Bijan to Turan.

If I want to be that cup of the universe, I will be at the feet of God ... I will tell you wherever you want to go, to the cup, this word of mine is clear to me (Ferdowsi, 1394: 2/660).

In mystical texts, the symbolic heart is the embodiment of a myth which, in addition to showing the state of the world to the mystic, is the manifestation of truth. Accordingly, Sheikh Ahmad Ghazali, considering the heart as a symbol of Jamjam, referring to the myth of Jamjam, says:

Until the World Cup is in my hands, it is my post from the wisdom of the wheel

There is no qibla until there is a qibla, I am the most conscious creation of the drunken world (Ghazali, 1388: 31). 
According to the Torah and the Qur'an, Solomon is one of the prophets and kings of Israel. In the Qur'an, Solomon commands humans, goblins and the court by the command of truth. The story of his prophethood, kingdom, glory, and greatness is summarized in verses 12 and 13 of Surah Saba. Dr. Sadegh Goharin, quoting the stories of the prophets, knows Suleiman's greatness and glory in a ring on which the Almighty had written many letters to him. (See: Attar, 1371: 317). In Persian literature, the glory and kingdom of Suleiman is equal to that of Jamshid, the mythical and famous king of ancient Iran. According to Shahnameh narrations, Jamshid also rules the court. At his command, they prepared a decorated throne court, and placed Jamshid on it and took him to the heavens. "This is impossible because it is more than a thousand years apart," said Tha'labi Marghni. (Tha'labi Marghni, 1372: 44). Tha'alabi also narrates two different narrations about the end of Jamshid's work. In the first narration, Jamshid, like the narration of Ferdowsi's Shahnameh, is cut in two with a saw. In the second narration, he says: "Some people think that Zahak threw the jam to the predators so that they tore him to pieces with his claws and teeth." (Ibid: 947).

Aware of such myths, Sanai, by combining Jam and Suleiman's ring, considers Jamshid and Suleiman as a single character, referring to the story of Suleiman's disappearance, addressing himself who is trapped in lust and selfishness:

Under the trap of Ashwa, for a while, Sanai was brewing. Sometimes it came to an end. One of the traps and the brewing of the tail of your relatives remained permanently in the trap of the demon.

Referring to the myths of Jamshid, Jamjam, Suleiman and the Ring, Sanai, while condemning the people of his time, considered their dark days to be a mixture of good and evil, the Prophet with Abu Lahab and Sulayman and Jamshid with the devil, says: It is a matter of judgment that Jam is distinguished from this people. Now the demon is with Khatam and with Jam (Ibid: 82).

The existence of common features between Jamshid and Sulayman has caused Sanai in the following verses that have been written in the description of the Prophet of Islam; He likened the role of love and affection of that Imam to the role of "Khatam Suleiman" or "Khatam Jam" and said: O Jabin, you sealed every embryo with the seal of your seal, unless you broke it a little. Jam, suddenly Khatam came out of his hand. His hand came out like an unseen inlay (Ibid: 657).

Sanai, who sometimes uses mythical allusions to praise the elders; While praising one of his praisers, he considered his knowledge and will superior to Jamshid's knowledge and will. He believes that just as Jamshid became aware of the secrets of the world and its conditions by looking at the World Cup, his praises also have such knowledge, and All the secrets of the heavens are known.

There is no pre-Reish covered on the sky.

Sanai in one of his Qalandaran lyric poems, using some mythical words and letters such as: Saqi, May, Jam, Kharabat, Zanar, Jamshid, Moghan, Zoroastrians, Rand, etc., which in later periods, in the poetry of great poets such as Hafez Frequency is used; Regarding the hasty passage of life, he says about the necessity of happiness, attachment to the world and its small blessings, and taking advantage of opportunities:

Saqia, get up and go to the cup in the ruins, ruin, calm down, fire of impurity in the wheel of a woman, dark dustJamshid Azarfam Kan, a professional prisoner (Sanaei, 1388: 981). 
Considering that the heart in mystical texts is a symbol of the World Cup and the manifestation of the beauty of truth, Roozbehan Baqli Shirazi, in the following beautiful quatrain, says:

I went in search of Jam Jam Jahan, I did not sit for a day and I did not sleep for a night

From Master Chou, I heard the description of Jam Jam. I was the world cup of Jam Jam (Baqli Shirazi, 1987: 49).

In the theology, Attar considers intellect and wisdom as a symbol of the sum of myths, and considers reaching perfection in the annihilation of truth. In the third article, he demands the third child from Jamjam's father. Jam Jam is neither a wind nor an interpretation of it, and only expresses the ambitions of the king's sons. In describing the oneness of God at the beginning of the tragedy, referring to the story of the creation of man and some myths such as Jamshid, he likens the blowing of the divine spirit in the earthly body of man to a treasure of divine knowledge:

Praise be to the pure soul of the pure one who gave the caliphate a handful of soil ...

In his heart he placed a treasure of knowledge given to him by Jan Jam Jam, the same adjective (Attar, 2007: 122-119).

Attargah, while referring to the myth of Jamjam or Jamshid's wine cup, uses it as "I love", which has a completely mystical meaning. Jamjam, in its mystical context, is a means by which the mystic is deprived of the truth of love in such a way that when it is broken, the seeker becomes confused and astonished.

The shower of your love came from my heart, I did not sit on my feet out of zeal

He said: Sit down and drink the cup in ten of the cups, I am drunk ... (Ashrafzadeh, 1373: 133).

It seems that in Attar's view, the water of life alone does not give eternal life to the mystic in love; For this reason, Attar used it in the form of melancholy and khezr water, by expressing such combinations, in addition to increasing the power of the cup, he believes that this cup not only intoxicates man, but also pours water of life into the mouths of those thirsty for knowledge. As in the following verse, in order to emphasize and exaggerate as much as possible, he used the cup and the water of Khidr with the hand of Jesus, who is healing and life-giving.

The cup full of water from Khezr's hand is still eaten by Jesus because it is eaten, a syrup from his life-giving cup (Ibid: 134).

In Attar Gah Jamejam's poem, like an old man and a skilled guide, he guides the seeker to reach the truth of love, which is to find eternal life. In the following verses taken from the court; The old man is the epitome of the myth that Attar, according to his mystical beliefs, considers it impossible to follow the path of mysticism except through the skill and wise tactics of this old man, who is aware of the secrets of the world.

I will share everything I have with the world without knowing it

Because the animal's water is in the dark, I will put the jam in my hand (Ibid: 135).

In his works, Attar, while referring to myths, either expresses a mystical concept or gives moral advice to the reader. As in the Divan of Poetry, while referring to the power and glory of Jamshid's 
kingdom, he considers it perishable and refrains from losing the kingdom and glory of Fereydoun, Jam, Kaykhosrow and Noshrvan.

Whether you are from Rome or China, neither the emperor nor Khaqan remained

From Afridon and from Jamshid Dardaz Kikhosroo from Noshravan Darigha (Ibid: 123).

Attar, who, by ignoring the glory and power of his predecessors, has in fact reached a kind of intellectual richness and piety to reach the truth; He sees the world as unfaithful, and the kingdom of Jam as unstable, and says in the necessity of attaching oneself to the world and its meager scales and seizing opportunities:

We sought fidelity in the face of the world, but it was not certain

Since the kingdom of Jam is not left, Javid drinks in memory of the kingdom of Jam (Ibid: 123).

The heart is used in various themes in Mursad al-Ebad Najm Razi; sometimes it is like a mirror and the sky, sometimes it is a tool of the soul to understand divine knowledge, and sometimes it is a symbol of a mythical complex, which in addition to showing him the state of the world, is the manifestation of beauty. Based on this belief, in expressing the purification of the heart on the law of the path, he deals with the mystical theme that attention to the unrighteous prevents man from reaching the right. On the other hand, paying attention to the truth and paying attention to the heart from God Almighty eliminates heart diseases and brings the seeker closer to the truth. Just as Ibrahim (AS) found himself sick because he looked unrighteous; And when he paid attention to Hazrat Haqq with the mirror of his heart, he said, "I am innocent, but do not associate others with this face, the face of which is the nature of the heavens and the breadth." (Najm Razi, 1371: 194). Najm Razi knows the lights that shine on the heart in two ways: the light of truth that shines on the heart from the truth and the unrighteous lights that are received from the external world through the senses. As Prophet Ibrahim, seeing the fall of the moon and the sun and the stars, did not consider those lights as the light of truth and argued with the polytheists. But if the mirror of the heart is pure, "these observations are seen in the unseen world from the world of the heart through imagination, and sometimes it is seen in martyrdom. "From the apparent world through the senses." (Ibid: 305-304). Najm Razi, while referring to some myths such as the seven levels of the sky and the seven climates, by comparing the heart to the sky and the body to the earth, justifies this similarity by saying: The sun of the soul shines from the sky of the heart on the earth and illuminates it with light and life. And "as the earth has seven climates and the sky has seven floors, the mold has seven members and the heart has seven as seven as the sky according to my creation, and as each climate of the earth has a different property and a kind of action arises from it. "If it is not in other climates, each member of the human being has a different quality and a kind of action arises from it that does not arise from the other member." (Ibid: 195). Najm RaziIn the introduction of Mursad al-'Abbad, while likening the heart to a mirror, he calls the summary of the human soul the heart and both worlds its pods, and says:

The meaning of the existence of man and soul is a mirror. The meaning of opinion in the two worlds is a mirror. The heart is a mirror of imperial beauty, and both worlds are the pods of that mirror (Ibid: 3).

In Mursad al-'Abbad, the heart is one of the tools of the soul to understand the world of the unseen and the kingdom. The author enumerates various external and esoteric evidences for the 
soul, instruments and devices, and says: The five external senses are among the external instruments and devices of the soul, which comprehend the world of intuition, and what these five senses are unable to comprehend, "that world It is the unseen with its multiplicity of levels and degrees, and it perceives it as five esoteric evidences, such as: intellect, heart, head, soul and secret. (Ibid: 117). Najm Razi, as it is mentioned in mystical texts, considers the heart as the manifestation of divine beauty, and the summary of the soul, but he considers conditions for it, and says: "The summary of the human soul is the heart, and the heart is the mirror, and both worlds are the mirror sheath and emergence." All the attributes of beauty and glory and the divinity through this mirror: "Our verses are in the horizons and in themselves." (Ibid: 3).

Considering that in mysticism, the adorned heart of the mystic is in fact the same as the collection of myths, which shows the state of the world to the mystics and by removing the impurities, becomes the manifestation of divine beauty. Rumi also believes that the heart of the mystic is such that it can be the manifestation of the essence of truth. In religious and mystical texts, in the definition of the throne, which literally means the throne and throne of kings, and in the term the throne of the Lord of the worlds, some commentators have said that the meaning of the throne and the throne is the expression of God's presence and dominion over everything, otherwise God is greater than it Who lean on a chair and a bed. (See: Yahaghi, 1375: 304). Rumi, according to the same theme, knows the place of God not in the thrones and heavens but in the hearts of the believers and quotes God, addressing human beings:

I do not belong to the earth, the sky or the throne, this dear believer

Let me be in the heart of the believer, oh! If you seek me, seek those hearts (Rumi, 1369: 1/129).

Jamshid is a symbol of glory and power in Persian literature, and in mystical texts is the basis for expressing many mystical and moral concepts. Rumi has given Jamshid a spiritual face by placing Jamshid next to the name of Jesus in the Mafia. He considered Jamshid as a symbol of soul and body, and the demon as a symbol of body and body. By juxtaposing the two, he expressed the contradiction of soul and body and told the story of how Jesus was born: Because Mary was in pain to give birth, He turned to the withered palm tree, and it withered away. Our body is like that palm tree. "If we are in pain, Jesus will give birth to us, and if there is no pain, Jesus will return to his origin through the secret way he came, otherwise we will be deprived." (Mowlana, 1385: 37).

Life from the inside to the forehead and nature from the outside to the leaves of the demon from the stew to Hayzeh and Jamshid fasting (Ibid: 37 ).

In the following verse, which is taken from an ode in praise of "Sheikh Baha'uddin Zakaria Multani", an Iraqi attributes the cup once to Kaykhosrow and once to Jamshid and says: Let's drink jam in the party.

We have Kaykhosrow's cup on the floor, so maybe we will join Jam Jam in a party (Iraqi, 1375: 89).

In another poem, which he composed in praise of "Sheikh Aziz al-Din Muhammad al-Hajji", referring to the mythical cup of Kaykhosrow, he says: Whenever the pure heart and adornment of Sheikh Aziz al-Din are engaged in mentioning the truth, it is as if the cup of Kaykhosrow is in his hands. Is, to be aware of the state of the world by looking at it. 
The emblem of Kikhosrow's cup, which is said to show his pure conscience at the time of dhikr in Junbad (Ibid: 70).

Considering that in mystical texts, Jam Jam is a metaphor from the heart of the mystic, which, by removing the impurities from it, becomes the manifestation of the secrets of truth. The cup in Hafez's Divan is used in two senses: the cup of May and the heart of the mystic. "In the cup, the mystic filters the secret of Dehr and sees the first and last truths in the mirror of the cup ..." (Khoramshahi, 1371: 1/565). During the turbulent years of Shiraz, Hafez creates a mirror of the situation of epic heroes and mythical kings for those who have instructive visions. In his sonnets, he mentions the glory and beauty of Jamshid and Jam Jam with great regret and lessons. He believes that as the only name left from the throne of Jam and the officer of Kikavus, neither the glory of kings is a remnant, nor the beauty of beauties lasts. Therefore, like Khayyam, he believes that the tail should be spoiled.

The glory of the kingdom and goodness, who gave stability? There is a word left from Takht-e Jam and Officer Ki (Hafez, 1371: 584).

Considering that most of the narratives about Alexander's mirror use the concept of camera, worldview and perspective; In Hafez's poem, sometimes the heart is likened to Alexander's mirror, Hafez "examines the role of the ruin and destruction of the wealthy king in the mirror of Alexander." (Zarrinkoob, 1371: 68). In Hafez's view, Jamjam is like the mirror of Alexander. "That is, exactly the same concept that has been more explicitly attributed to" Jam Jam "and the mirror of the worldview in Iranian literature and mysticism." (Yahaghi, 1375: 55). From Hafez's point of view, just as Alexander's mirror on the top of the Alexandrian minaret showed the movement of ships from afar, so the cup, which is a metaphor of the mystic's conscious heart, shows him the state of the world.

The mirror of Alexander is the cup, look at what he has to offer you(Hafiz, 1371: 8).

Pir Mikhaneh, who is Hafez's guide in the path of mysticism, is sometimes a symbol of the World Cup, who gives his world cup to Hafez at dawn, when the mystics are alone and the secrets and needs of lovers, so that he can clearly see the beautiful front of Jamal Yar.

The old tavern gave me the dawn of the World Cup, and there I made a mirror of your goodness (I know: 491).

According to the myths and theology, Jam Jam was a cup in which they saw the state of the world. This cup has a week of lines or degrees, which are: "Jour, Baghdad, Basra, Arzaq, tears, bowl and drop." (Ashrafzadeh, 1386: 2/1604). According to such beliefs, in the following verse, Hafez considers Jam Jam to be the heart of a mystic, and says:

Whoever read the secret of the two worlds from the Saghar script knew the secrets of Jam Jam from the role of soil (Ibid: 67).

Hafez, who considers the heart of the mystic as the mirror of the cup, the manifestation of existence, in the following mystical sonnet, while referring to the cup (the heart of the mystic), bows his head before the eternal beloved: 
The picture fell on you in the mirror of the cup. The mystic fell from May's laughter into raw greed (Ibid: 149).

According to mythological narratives, although Jamshid and Kaykhosrow were aware of the unsolved mysteries of the universe due to having the World Cup, they realized well that selfattention is a barrier to reaching the goal, and eternal survival is in the unconscious. From Hafez's point of view, in the following beautiful sonnet, the true seeker is none other than the heart. The real heart and the heart, not Glenn, as stated in the words attributed to Bayazid Bastami, "That heart of the heart, not the heart of Glin." (Zarrinkoob, 1371: 244). In this interpretation, the real goal of the seeker (heart) of Jam Jam is the awakened conscience that has liberated man from himself and guided him unconsciously. Such a cup was very important for Hafiz. He considered all his intoxication as a sign of it, emphasizing that whoever serves in such a cup, sees everything as it is, as if: from the property to his kingdom, they take the veil. (See: Ibid: 147-146). Once in Hafez's poem, the heart is not the same as the World Cup, in which only the face of the beloved appears.

For years, he begged for Jam Jam and asked for what he had from a stranger (Hafez, 1371: 193).

In the poetry collection, Jami sometimes mixes Jamshid and Suleiman, and attributes the glory of one to the other. As in the following verse, he mixes the cup and Persepolis with the prophet Solomon, and referring to this beautiful story, says:

The bed is jammed with the wind waiting for the ring to announce (Jami, 1378: 2/566).

Jami sometimes mixes some Semitic myths with Iranian myths. As in the following verse, Negin attributes the tamer of demons to Jamshid, and says:

It was a jewel that belonged to the king of Anas and the jinn (ibid .: 1/807).

\section{Kaykhosrow}

Kikhosrow has been mentioned in various parts of the Avesta, especially the Yashtes. In verse 38 of Arat Yasht, which is the name of one of the gods of the Zoroastrian religion and the guardian of wealth and property, referring to the kinship of Kaykhosrow from Afrasiab, it is stated: "... You have bestowed this success on me, the noble Arat Nik, who imprisoned Afrasiab Turani. Bring and pack, and pack. Closed for Kikhosrow (Boram) to drag him in front of the deep and wide (wide) lake of Gechest. "That punishing son of the brave Siavash who was betrayed and bravely betrayed Kane." (Pourdaoud, 1394: 2/597). In Abanisht, Kaykhosrow is one of the writers and kings of Kianiya. In the 17th, 18th, 21st and 22nd verses of Yasht or Dervasp Yasht, Afrasiab is captured by Kaykhosrow, Kaykhosrow is one of those for whom ransom is brought. In two or thirty days, big and small, the name of Kaykhosrow has been praised. Among his good and lasting deeds is the destruction of an idol on the top of Sahand Mountain in Ardabil, and the construction of the Azargashsab Fire Temple with the help of Foroughi, who was sitting on his horse's guide to guide him: "He guided and removed the darkness of the fort, after which Kaykhosrow put the fire in a temple on the top of Mount Snont in the same place." (Ibid: 381). Kaykhosrow is one of the immortals in Avesta, and one of the prominent ones in Pahlavi texts; Before the advent of Zoroaster, he was aware of the ritual of Ormazd. According to Pahlavi narrations, he disappears but does not die; He hides in a mysterious place, and has the task of awakening Garshasb during the time of "Sushyans", and guiding him to the religion of Zoroaster, then asking him to laugh at 
Zahak, who was imprisoned by Fereydoun until the end of the world, and in the millennium of "Oshidrmah". He will be released from prison, he will be released. (See: Teacher, 2016: 79).

In Shahnameh, Kaykhosrow is one of the most famous, popular and influential kings of Kiani. As the strength, success, beauty, glory and victories he achieved with Far's help amazed everyone. According to the narrations of Shahnameh, Kikhosrow, looking at the World Cup in Hormozd Rooz, became aware of the well in which Bijan was trapped and sent Rustam to Turan to save him. After Shahnameh, this cup also found its way to lyrical stories. As in the story of Salaman and Absal Jami, "After escaping Salaman and Absal, the king uses the mirror of the universe to find them." (Zolfaghari, 1394: 89). The ascetic kingdom of Kikhosrow and the unwise rule of Kykaus are two different models of Shahriari in Shahnameh. Ferdowsi's praise of Kaykhosrow's model and his hatred of Kykavs's model is a clear sign of the importance and status of asceticism and piety in Iranian culture and Ferdowsi's view. Also, some of the legends and narrations about the life and kingship of Kaykhosrow did not make him a great Cyrus. Makes one. However, one of the greatest and most prominent aspects of Kaykhosrow's life is his ascetic and mystical aspect, which sought to bring about a great spiritual transformation in him and forced him to relinquish the kingdom and turn to asceticism and seclusion. "The story of the end of Kaykhosrow's work and his four takbirs on everything is like this by choosing death before death and joining this preparation to immortality and immortals." (Serami, 1392: 85). This spiritual transformation can be seen in the later periods in the lives of many mystics, including Ibrahim Adham. Therefore, in mystical texts, Kaykhosrow is mentioned as the leader of Ibrahim Adham. After praying for the glory of Shahriari, the world and its blessings at the end of his life, he prayed to God for a week and one night he saw in a dream that Soroush gives him the good news of a Minoan journey. He chose Lohrasb as his successor and went on a never-ending journey with a few heroes. In the evening he sat in the springs and in the morning no trace of him was found. Describing this irreversible journey, Ferdowsi says:

In such a dream, you can hear Koo lying in your ear and say, "Blessed is Soroush, that $\mathrm{O}$ good king, Akhtar, good fortune, enough help and throne." If you are in the fast-paced world, now you have found what you are looking for: in the neighborhood of a pure judge, find a place, in this darkness in the map! (Ferdowsi, 1394: 2/893).

The reference to various aspects of Kaykhosrow's life, especially the ascetic aspect of his life, has been widely reflected in mystical texts. Contrary to the Shahnameh narration, Shahab al-Din Suhrawardi has narrated another narration from the end of Kaykhosrow's work, saying in this regard: The end of Kaykhosrow's work is that his heavenly father called him to himself. According to Suhrawardi, this heavenly father is none other than the same human lord and the mighty light that Sheikh Ishraq described in the "Temple of Light" as follows: And he is the lord of the spell of the human race; And He is the mediator and giver of our souls, and the complement of man; "And the Shari'ah calls him the Holy Spirit, and the people of wisdom call him the active intellect." (Asadpour, 1389: 13). In Suhrawardi's enlightened view, Kaykhosrow is someone who, like the prophets, is connected to the Holy Spirit and, like the sages, to the active intellect and has reached the mystical stage of the annihilation of truth. This part of Kaykhosrow's life is in fact the transition stage of epic to mysticism, and at this stage of his life, Kaykhosrow transforms from an epic myth to a mystical myth. Suhrawardi, like other mystics, concludes from the story of Kaykhosrow and the cup in which he became aware of the state of the world that this cup is nothing but adorned and free from impurities; The cup is symbolic and everyone can achieve it if 
they give themselves the cup they deserve. The picture that Suhrawardi gets of this cup is as follows: This cup is in fact the heart of the mystic or his luminous soul, which is imprisoned in the leather sheath of the body, with ten strong straps of ten outward and inward senses. Light also has a special meaning in Suhrawardi's Enlightenment philosophy. Just as the sun means spiritual sunshine, and Suhrawardi mentions it in various cases. In describing the man trapped in the exile of the body, "what Suhrawardi intended to achieve in his school is to draw a map that shows the human ontology trapped in the exile of the Western world, which is the material world, and by means of the desired map "The east of the universe, which is the illuminated world or the heavenly realm, has found its way to the prison of carnal lusts." (Bakhshandeh Bali, 1389: 35). Suhrawardi says about the Gitnama Cup, which is attributed to Kikhsaro in the Shahnameh, in Moran's dictionary: "The Gitnama Cup was Kikhosrow. Whatever you wanted, you studied there and became aware of the universe and learned about defeats. It is said that it was a sheath made of edema in the shape of a cone, with ten open straps placed on it. When you wanted to see something of the defects, you put that sheath in the nest. Because you had untied all the straps, you did not come out, so when the sun was in the equator, he was facing the cup. When Akbar Nayr Akbar came to him, all the motifs and lines of the universe appeared there.

Zastad Choo, I heard the description of Jam Jam

The World Cup is called that old cup of our wool (Asadpour, 1389: 14).

This cup, in addition to being a metaphor from the heart of the mystic, is a symbol of the lesser world, which is itself a mirror that reflects the greater world. Suhrawardi considers the way to reach this light and release it from the bonds of Edim, says that if we want to open the bonds of this lock, the cup will disappear and it will fly to the east outside this world. Therefore, this cup is visible as long as it is in contact with its leather sheath (body). In Suhrawardi's enlightened view, Kaykhosrow is a metaphor of the soul and spirit that belongs to the upper world and the heavens, which reached the heavens by freeing itself from the shackles of this world.

Although the reign of Kikavs is one of the busiest and darkest periods, and in which the two great tragedies of Sohrab and Siavash take place, things are settled with the reign of Kikhosrow, and the course of events changes in favor of the Iranians. Tha'labi Marghni, while likening Kaykhosrow to the angels of the Divine Court, reigned over"At this time, the people were relieved by the bad governance and the bad temper of Kikavous and his failure to run the country," he said. "And they were relieved of the affliction and loss of Afrasiab, and of his armies, and of the perpetual affliction of his day: and they found angels in the king's face instead of Kikavus and Afrasiab." (Tha'labi Marghni, 1372: 151).

Najm Razi in his book Asadi's Mysteries in Davoodi's Mysteries, while making a brief mention of the reign, and referring to the ascetic aspect of Kikhosrow's life and how he became ascetic, says: "It was his work and his asceticism." (Najmuddin Razi, 1352: 88).

Kaykhosrow in the sonnets of Shams is a symbol of glory, power and kingdom. Rumi, by mentioning the name of Kaykhosrow along with the name of Sultan Sanjar of Seljuk, describes their glory and power as follows:

Listen to Baba and the tower that the Sultanate calls for the land of August Kikhosrow to die before him Sanjar (Rumi, 1386: 345). 
Rumi calls himself not only a slave of love but also a slave of love. In the following verse, the fire of love has ignited him so much throughout his existence that he is proud of the servitude of the servants of love, he considers himself the servant of Kaykhosrow and Kiqbad, who are also the servants of love.

Because we are the servants of our love servants, Kikhosrow and Kiqbad (Ibid: 511)

Given that in the profession of love, lovers have nothing to do with far-sighted wisdom. The lover has lost his intellect and wisdom in the way of love, his heart and soul are flying to the friend in the heavens, without having the flag and umbrella of the kingdom, he is Kikhosrow and Sultan.

Those lost minds and hearts, the souls of the slaves without umbrellas and the pin of each of them became Kikhosrow and Sultan (Ibid: 750).

In Shahnameh, Kaykhosrow is the most influential among prominent figures and mystics, such as Fereydoun, Iraj and Siavash. Iraj and Siavash consider the world invalid, do not consider it worthy of attachment and support its kingdom and glory. In the middle of his life, when he could enjoy the blessings of life and the glory of the kingdom like others, Kaykhosrow turned away from it, turned to seclusion and mystery and need with God, and listened to what he heard from Soroush and put it into practice. How he was born, boasting, good character, justice, having Farkiani and the World Cup - which is originally attributed in Shahnameh - good speech, good deed and good thought, quarrel with Afrasiab, - which like the devil is a symbol of destruction and evil - the end of life And how he disappeared has created many symbols about him, giving him more than anyone else, mythical, epic and mystical figures. Kaykhosrow has a prominent place in religious and Zoroastrian texts. In Zoroastrian mythology, at the end of the fourth millennium, he rises to the aid of Sushyans. Hence, "in the Zoroastrian religious narrations and in the Avesta, he is mentioned as the one who rides on the heavenly Soroush who returns in the end times and rises with the help of Sushyant." (Dostkhah, 1370: 600). Based on these beliefs and considering the unique mythical and mystical features of Kaykhosrow, Rumi establishes a poetic connection between him and the moon and says:

All of them are in the fish, all of Kikhosrow and Shahi are all like Yousef Chahi from you in what darkness (Rumi, 1386: 926).

In the third book of Masnavi, Rumi, in a beautiful story, while referring to the myths of Kikhosro, says that "becoming Kikhosro", "becoming Khosro" and "becoming the moon" mean reaching perfection:

Khajeh and the children built a device and attacked the stars on the side of ten

They happily drove to the desert and chanted Safrova Ki Taghnmova

When travels become the month of Kaykhosrow, without travels, when does Khosrow become?

Be careful of travel Farzin Rad Kaz, travel Yousef Sad Morad (Molavi, 1369: 3/31). 
Considering that mystics consider the real treasure not in the accumulation of wire and gold, but in love with the beloved and the Imam. Qasim Anwar considers the kingdom of Fereydoun and the treasure of Qarun to be worthless and dignified in the face of the treasure of the heart (love):

If love is not with you, what is the benefit of Qarun's treasure and Kaykhosrow's property? (Anwar, 1337: 267).

\section{Conclusion}

Zoroaster, the prophet of ancient Iran, Jamshid, the greatest pioneer prince, and Kaykhosrow, as the most famous and ascetic figure of Avesta and Shahnameh, are among the personalities who have a large part of the culture and beliefs of ancient Iran, Shahnameh, literary and mystical texts. In addition to the epics and myths of the Shahnameh, which have had a profound effect on the mystical texts of later centuries, the beliefs, customs, and intellectual, religious, social, and cultural backgrounds of the ancient Iranians have already provided favorable conditions for the creation, growth, and development of Iranian-Islamic mysticism. . Accordingly, the close links between Zoroastrian myths and epics, and the Shahnameh, cannot be ignored with Iranian-Islamic mysticism, which has occupied a large part of Persian literature. Given such connections, it seems necessary to state a few key points that are the result of this research. First, prominent religious, epic, and mythological figures such as Zoroaster, Jamshid, and Kaykhosrow have left extensive and influential reflections on mystical texts. Secondly, such themes have found their way into mystical texts with many changes. Third, the main purpose of mystics in referring to these themes is to express religious, mystical, mystical, and moral concepts, not to mythology, epicism, or attachment to them. The other is that religious, epic, and mythical themes have found broader meanings after entering mystical texts and have been used in a variety of themes. The last point is that the connections are negativeThe religious, epic, and mythological motifs of ancient Iran and the Shahnameh with mystical themes, in addition to showing the deep links between ancient Iranian culture and Iranian-Islamic mysticism, reflect the fact that after Islam, Iran was the greatest mystics and mystical works. It has grown in its skirt, and has provided the grounds for the growth of Persian literature and the spread of Islamic mysticism.

\section{References}

The Holy Quran.

Teacher, Jaleh. (1395). Mythical History of Iran, Seventeenth Edition. Tehran: Samat. Asadpour, (1389). Symbolism of ancient Iran in Suhrawardi Persian treatises. Semester Specialized Journal of Religion Research. Year 4. Number 7.

Ashrafzadeh, Reza. (1373). Manifestation of mystery and narration in the poetry of Attar Neyshabouri. First Edition. Tehran: Myths.

Headless hats. First Edition. Mashhad: Saleh.

Literature of recycled literature from previous texts. First Edition. Mashhad: Sokhan Gostar.

Anwar, Qasim. (1337). General Qassem Anwar. Correction, confrontation and introduction: Saeed Nafisi. First Edition. Tehran: Sanai 8- Bakhshandeh Bali, Abbas. (1389). Red Wisdom Song. (Review of Sheikh Ishraq's thoughts). First Edition. Tehran: Kanoon.

Baqli Shirazi, Roozbehan. (1366) .Correction and introduction: Henry Corbin and Mohammad Moin. Third edition. Tehran Manouchehri. 
Purdavood, Ibrahim. (1394). Avesta. First Edition. Tehran: Negah.

Thalabi Marghni. (1372). Old Shahnameh. Persian Battalion: Mohammad Rouhani. First Edition. Mashhad: Ferdowsi University.

Jami, Nur al-Din Abdul Rahman bin Ahmad.

Introduction and correction: Alakhan Afsahzad. First Edition. Tehran: Ministry of Culture and Islamic Guidance.

Hafiz, Shamsuddin Mohammad. (1371). By the efforts of Khalil Khatib. Ninth edition. Tehran: University of Tehran.

(1372). Divan of Khajeh Shamsuddin Mohammad Hafez Shirazi. First Edition. Tehran: Stars.

Hekmat, Ali Asghar. (1363) Includes research in the history of the life and works of the poet and prose of Khatam al-Shoara Nooruddin Abdul Rahman Jami. First Edition. Tehran: Toos.

Khorramshahi, Bahauddin. (1371). Memory. fourth edition. Tehran: Scientific and cultural.

Dostkhah, Jalil. (1370). Avesta, the first Iranian songs. Third edition. Tehran: Toos.

Zolfaghari, Hassan. (1394). One hundred Persian love poems. second edition. Tehran: Charkh.

Zarrinkoob, Abdul Hussein. (1369). In search of Sufism. fourth edition. Tehran: Amir Kabir.

From Rendan Alley. About Hafez's life and thought. Seventh edition. Tehran: Amirkabir.

Sarami, Ghadmali. (1392). From the color of flowers to suffering. Sixth edition. Tehran: Cultural Science.

Sanai, Abolmajd Majdood Ibn Adam. (1387). Edited by Mohammad Taghi Modarres Razavi. second edition. Tehran: University of Tehran.

Sanai, Majdood bin Adam. (1388). Introduction and list to the efforts of Mohammad Taghi Modarres Razavi. Seventh edition. Tehran: Sanai.

Iraqi (Hamedani), Fakhreddin Ibrahim. (1375). Generalities of Iraq. Corrected by Saeed Nafisi. Eighth edition. Tehran: Sanai.

Attar Neyshabouri, Fridaldin. (1371). The logic of the bird. By SadEighth edition. Tehran: Scientific and cultural.

—_ - Corrected by Mohammad Reza Shafiee Kadkani. Third edition. Tehran: Sokhan

Ghazali, Ahmad. (1388). accidents. According to Qasem Kashkoli. First Edition. Tehran: Third.

Ferdowsi, Abolghasem. (1394). Shah nameh. Trimming the glory of the Absolute Creator. First Edition. Tehran: Sokhan.

Kazazi, Jalaluddin. (1383). Ancient Letter. Second Edition. Tehran: Samat.

Mohammad Ibn Munawwar. (1371). Secrets of Tawhid in the authorities of Sheikh Abi Saeed. Introduction, correction and comments: Mohammad Reza Shafiei Kadkani. Twelfth edition. Tehran: Agah. 
Mawlawi, Jalaluddin Mohammad Balkhi. (1369). Masnavi. Corrected by inquiry, Mohammad. second edition. Tehran: Zavar.

Mowlana, __ (1385) Based on the version of Master Badi-ol-Zaman Forouzanfar. By the efforts of Zeinab Yazdani. fourth edition. Tehran: Tirgan.

(1386) - - -Generalities of Shams Tabrizi. Correction of the novel of the time of Forouzanfar. First Edition. Tehran: Parseh.

Molaei, Mohammad Sarwar. (1368). Manifestation of myth in Hafez's poetry. First Edition. Tehran: Toos.

Najmuddin Razi. (1352). Asadi mysteries in chrysanthemums. First Edition. Tehran: University of Tehran.

Najm Razi. (1371). .By Mohammad Amin Riahi. fourth edition. Tehran: Scientific and cultural.

Vahidi, Hassan. (1393) .First Edition. Tehran: Afrineh.

Hinels; John. (1397). Understanding Iranian mythology. Translated by Jaleh Amoozgar, Ahmad Tafzali. Twenty-first edition. Tehran: Cheshmeh.

Yahaqi, Mohammad Jafar. (1375). Culture of myths and fictional allusions in Persian literature. second edition. Tehran: Soroush.

Yathribi, Yahya. (1385). The Wisdom of Suhrawardi Illumination. First Edition. Qom: Book Garden. 